\title{
Kita Penakut
}

Jika kita ingat kembali masa dimana kita begitu antusias menyebutkan semua impian kita. Masa dimana tak ada keraguan sedikitpun apakah mimpi itu akan terwujud atau tidak, dan masa dimana hanya dengan membayangkan impiannya saja kita sudah bahagia.

Namun jika kita lihat kita yang sekarang, rasanya kita menjadi pribadi yang begitu penakut. Jangankan untuk mewujudkan mimpi memiliki mimpi pun kita takut. Takut pada hal-hal yang sebenarnya belum tentu terjadi. Kita menjadi amat sangat penakut bahkan untuk sekedar membayangkan saja, pada akhirnya memilih untuk menyerah dan pasrah pada keadaan.

Kita yang dewasa terlalu banyak berpikir resiko gagal, padahal jika setiap langkah yang kita ambil terarah, kita pasti akan sampai. Kita harus tahu kapan kita akan mulai, kemana kita akan sampai, dan perjalanan apa yang akan kita lalui. Orang-orang sekarang jika ditanya tentang impian, harapan ataupun citacita, tak jarang orang mengatakan saya tidak tahu atau banyak orang yang menjawab ikuti saja alurnya dan biarkan mengalir seperti air. Perlu kita tahu bahwa air itu selalu mengalir ke tempat yang rendah.

Tak ada salah nya kita membuat rencana. Jika ada yang bilang untuk apa punya rencana, takdir sudah ada yang menentukan. Tapi bukankah setiap kita menginginkan takdir yang baik ? kenapa tidak diusahakan ? bukankah ada sebagian takdir yang bisa kita rubah dengan ikhtiar dan doa?

Jika kita sudah paham maka tak ada salahnya kita merencanakan masa depan. Walaupun nanti apa yang kita usahakan tidak sesuai dengan apa yang terjadi, setidaknya kita sudah berusaha. Dan itu akan lebih melegakan daripada kita hanya diam menunggu takdir yang menyapa.

Ada satu kalimat motivasi "There is no guarantee of success. But not trying is a guarantee of failure." Artinya "Tidak ada jaminan sukses. Tapi tidak mencoba adalah jaminan kegagalan."

Sebenarnya banyak faktor yang mempengaruhi mengapa kita saat ini sangat takut terhadap segala sesuatu, terhadap hidup, impian, dan sebagainya. Salah satunya karena kita sedang berada di fase Quarter Life Crisis. Yaitu satu fase kehidupan dimana kita mengalami krisis terhadap segala hal. Biasanya fase ini ada disaat kita berusia 18-30 tahun. Sebenarnya ini merupakan masa transisi kita dari remaja ke dewasa. Masa dimana kita banyak mencari, masa dimana kita memulai sesuatu. Itu hal- hal yang membuat kita bingung, sebenarnya apa sih tujuan hidup kita? apakah benar jalan yang kita ambil ?

Ada beberapa cara mengatasi hal tersebut :

1. Anggaplah bahwa hal itu adalah normal terjadi pada siapapun.

Bukan hanya kita saja yang mengalami hal tersebut, tapi semua orang pernah mengalaminya. Karena masalah hidup adalah sesuatu hal yang wajar. Maka persiapkanlah fisik dan mental yang kuat agar krisis ini tidak berkelanjutan.

2. Cari teman yang merasakan hal yang sama. 
Biasanya ketika kita mengalami hal ini, kita merasa sendiri, dengan mempunyai teman yang mengalami hal yang sama kita dapat saling berbagi dan kita bisa melewati fase itu bersama.

Beranikan diri kita untuk melangkah, memperjuangkan semua yang menjadi hak kita. Mulailah merencanakan ingin jadi seperti apa kita nanti, alasan mengapa kita menginginkan itu, apa langkah-langkah yang akan kita ambil agar semua impian kita terwujud. Persiapkan dan rencanakan dari sekarang, ikhtiarkan dan doakan dari sekarang. 